\title{
Antioxidant and Antibacterial Natural Products Evaluation from Terrestrial Streptomyces Species Strain KAV 2 Isolated from Rhizosphere Regions of Piper betle
}

\author{
Keerthana $\mathbf{S}^{\mathbf{1}}$, Abilasha $\mathbf{R}^{\mathbf{1}}$, Saraswathi $\mathbf{K}^{\mathbf{2}}$, Arumugam $\mathbf{P}^{*}$ \\ ${ }^{1}$ Department of Biotechnology, SASTRA Deemed to be University Tirumalaisamudram, Thanjavur - 613401 \\ ${ }^{2}$ Department of Biotechnology, Karpaga Vinayaga College of Engineering and Technology, Madhuranthagam, Kancheepuram - 603308 \\ * ARMATS Biotek Training and Research Institute, Guindy, Chennai - 600032
}

\begin{abstract}
Terrestrial actinomycetes have come to antimicrobial production dominantly and have been the focussed area for bioprospecting of novel secondary metabolites. The secondary metabolites of the fermented culture were prepared by solvent extraction method. In the current research work, Streptomyces species were completely analysed for antioxidant and antibacterial activities and also the GCMS analysis of the crude active extract revealed the presence of 12 bioactive compounds, which makes the particular strain as a potent source for drug validation research. The antioxidant activities assessed by four different methods proved that the crude extract could be effective against various kinds of free radicals. The maximum free radical scavenging activity for Ethyl acetate fraction by DPPH method was found to be $94.84 \pm 0.24 \%$ at 60 $\mu \mathrm{g} / \mathrm{mL}$ concentration and the $\mathrm{IC}_{50}$ value was $26.91 \mu \mathrm{g} / \mathrm{mL}$ concentration respectively. The maximum ferric reducing ability for Ethyl acetate fraction was found to be $81.83 \pm 0.48 \%$ at $120 \mu \mathrm{g} / \mathrm{mL}$ concentration and the $\mathrm{RC}_{50}$ value was $53.16 \mu \mathrm{g} / \mathrm{mL}$ concentration respectively. The qualitative screening for active compounds gave positive results for alkaloids, phenols, tannins, terpenoids, steroids. The Streptomyces species demonstrated antibacterial activities with maximum zone of inhibition as $19 \mathrm{~mm}$ against tested bacterial pathogens such as Micrococcus luteus and Bacillus subtilis.
\end{abstract}

Keywords: Streptomyces, DPPH`radical, ABTS •+ radical cation, antibacterial, GCMS

Article Info: Received 10 July 2019; Review Completed 16 August 2019; Accepted 18 August 2019; Available online 30 Aug 2019 Cite this article as:

Keerthana S, Abilasha R, Saraswathi K, Arumugam P,, Antioxidant and Antibacterial Natural Products Evaluation from Terrestrial Streptomyces Species Strain KAV 2 Isolated from Rhizosphere Regions of Piper betle, Journal of Drug Delivery and Therapeutics. 2019; 9(4-A):26-37 http://dx.doi.org/10.22270/jddt.v9i4-A.3390

*Address for Correspondence:

Dr. P. Arumugam, Industrial Fermentation Technology Division, ARMATS Biotek Training and Research Institute, Chennai - 600 032, Tamil Nadu, India

\section{INTRODUCTION}

The process of drug development from natural products is based on following two strategies: Assessment of biological activities of pure compounds (chemically driven method) and Bioassay-guided process which involves working with crude extracts (biologically driven method). The important characteristics of microbial bioactive compounds include their specific microbial origin, environmental interactions and unique chemical structures ${ }^{1,2}$. On a commercial scale, microbial products can be utilized in several ways such as direct application of fermentation produce in agriculture, medicine or any other sector. Products can be used as a starting material for derivatization process. The obtained compounds can act as leads in analogues synthesis and rational drug designing3,4. More than 50,000 microbial natural products (MNPs) have been obtained and have played an important role in drug discovery. The majority of these have been isolated from terrestrial-borne microbes. However, after 50 years of intensive screening from terrestrial-borne microbes, the pace of MNPs' discovery and development with a unique scaffold has dramatically declined over the last two decades 5,6 .

Natural products have a wide range of diversity of multidimensional chemical structures; in the meantime, the utility of natural products as biological function modifiers has also won considerable attention. Subsequently, they have been successfully employed in the discovery of new drugs and have exerted a far-reaching impact on chemicobiology 7,8,9,10. Natural product compounds (NPCs), especially those mined from microbes (bacteria and lower eukaryotes) are established resources for a variety of remedial agents. Such drugs of microbial origin ${ }^{11,12}$ have been classified as:

(i) Original microbial products. 
(ii) Products derived or chemically synthesized from microbial products.

(iii) Synthetic products based on microbial product structures.

Natural habitats, especially the soil-and plant-associated environments, are teeming with microbes that produce bioactive metabolites that shield them against extreme environmental conditions ${ }^{13}$. Microbial metabolites are among the most important chemotherapeutic agents in oncology. This aspect of microbes was identified as early as 1940 with the discovery of actinomycin from Streptomyces ${ }^{14}$. Among marine bacteria, Actinomycetes are the largest contributors of novel bioactive secondary metabolites accounting for $45 \%$ of total microbial metabolites (75\% from Streptomyces and $25 \%$ from rare Actinomycetes). A huge variety of antibiotics such as anthracyclines, aminoglycosides, glycopeptides, beta-lactams, macrolides, polyketides, actinomycins and tetracyclines have been isolated from Actinomycetes ${ }^{15}$.

Actinomycetes are prokaryotes with prostate mycelium grow on the substrate, and those with aerial mycelium grow above the vegetative growth. Gram-positive bacteria with their DNA high in guanine-plus-cytosine content (69-73 mol $\%)^{16,17,18}$. Streptomyces, a well-explored genus of Grampositive bacteria, is included in the phylum Actinobacteria. Currently it is reported that there are more than 2,400 different secondary metabolites produced by Streptomyces sp.18. Oxygen, while indisputably essential for life, can also participate in the destruction of tissue and/or impair its ability to function normally19,20,21,22. Oxygen-free radicals (OFR), or more generally, reactive oxygen species (ROS) are products of normal cellular metabolism. Free radicals can be defined as molecules or molecular fragments containing one or more unpaired electrons in atomic or molecular orbitals ${ }^{23}$. This unpaired electron(s) usually gives a considerable degree of reactivity to the free radical. Radicals derived from oxygen represent the most important class of radical species generated in living systems ${ }^{24}$. Molecular oxygen (dioxygen) has a unique electronic configuration and is itself a radical. In the ground state, it is a biradical with two parallel unpaired electrons in antibonding $\pi *$ orbitals thus forming a triplet state molecule ${ }^{25}$.

The vitamins $\mathrm{C}$ and $\mathrm{E}$ are thought to protect the body against the destructive effects of free radicals. Antioxidants neutralize free radicals by donating one of their own electrons, ending the electron-"stealing" reaction. The antioxidant nutrients themselves don't become free radicals by donating an electron because they are stable in either form. They act as scavengers, helping to prevent cell and tissue damage that could lead to cellular damage and disease. Vitamin E - The most abundant fat-soluble antioxidant in the body. It is one of the most efficient chainbreaking antioxidants available, is the primary defender against oxidation, and is the primary defender against lipid per oxidation (creation of unstable molecules containing more oxygen than is usual). Vitamin C - The most abundant water-soluble antioxidant in the body. It acts primarily in cellular fluid. It combats free-radical formation caused by pollution and cigarette smoke. Also helps return vitamin E to its active form ${ }^{26}$.

\section{MATERIALS AND METHODS}

\section{Sample Collection}

The soil sample was collected from the rhizosphere regions of Piper betle, Velachery, Chennai, Tamilnadu in sterile plastic bags during July 2017. The collected soil sample were transferred to sterile petri plate and was evenly spread, airdried at room temperature for a period of three days with standard microbiological methods.

\section{Isolation of Terrestrial Actinomycetes}

Pre-treatment process was carried out for the air-dried soil in order to reduce bacterial population. $0.1 \%(\mathrm{w} / \mathrm{v})$ Calcium carbonate was mixed with the soil and agitated gently to ensure proper mixing. The pre-treated soil was kept undisturbed for three days and the soil was agitated at regular intervals of time. The selective medium Starch casein agar (SCA) was preferred for isolating actinomycetes from the terrestrial soil. Serial dilution $\left(10^{-1}\right.$ to $\left.10^{-10}\right)$, followed by spread plate method was performed for the isolation process. The medium was supplemented with nystatin to prevent bacterial and fungal contamination. The inoculated plates were incubated at room temperature for seven to twelve days ${ }^{27}$. The selected actinomycetial colonies were purified by streak plate (quadrant) method and stored at $4^{\circ} \mathrm{C}$ on starch casein agar slants for further investigation.

\section{Preliminary Characterization of selected isolates}

\section{Colony Morphology}

Colony morphology of the purified actinomycetial isolates on SCA medium were recorded with respect to colour of aerial spore mass, size and nature of the colonies, colour on the reverse side and diffusiblepigmentation ${ }^{28}$.

\section{Extraction of secondary metabolites and compound recovery}

The selected isolate based on morphology, growth, etc. were inoculated in Yeast malt extract broth (or) International Streptomyces Project (ISP-2) medium aseptically. The inoculated broth was subjected to fermentation process at room temperature $\left(37^{\circ} \mathrm{C}\right)$ for ten days at $150 \mathrm{rpm}$ resulting in complete growth of the selected isolate. The fermented broth was filtered through sterile whatman No.1 filter paper, and the culture filtrate was centrifuged at $8,500 \mathrm{rpm}$ for 20 min. Equal volume of mid polar solvent ethyl acetate was added along with the supernatant in 1:1 ratio. The supernatant-solvent combination was kept in rotary shaker undisturbed overnight. The organic solvent phase was separated and evaporated to dryness ${ }^{29}$ and the crude extract were dissolved in specific solvents and further evaluated for antioxidant and antibacterial studies.

\section{In vitro Antioxidant activities of Ethyl acetate fraction of Streptomyces KAV 2}

\section{DPPH`radical scavenging activity}

The antioxidant activity of Ethyl acetate fraction of Streptomyces KAV 2 was measured on the basis of stable 1, 1- diphenyl 2-picrylhydrazyl (DPPH) radical scavenging activity ${ }^{30}$. One $\mathrm{mL}$ of $0.1 \mathrm{mM}$ DPPH solution in methanol was mixed with $1 \mathrm{~mL}$ of various concentrations $(10-60 \mu \mathrm{g} / \mathrm{mL})$ of Ethyl acetate fraction. The mixture was then allowed to stand for 30 min incubation in dark. Ascorbic acid was used as the standard reference. One mL methanol and $1 \mathrm{~mL} \mathrm{DPPH}$ solution was used as the control. The decrease in absorbance was measured at $517 \mathrm{~nm}$ using UV-vis spectrophotometer. The percentage of $\mathrm{DPPH}^{-}$radical inhibition was calculated as:

$$
\% \text { of } \mathrm{DPPH}^{-} \text {radical inhibition }=\left[\frac{\text { Control }- \text { Sample }}{\text { Control }}\right] * 100
$$




\section{Superoxide $\left(\mathrm{O}_{2--}\right)$ radical scavenging activity}

The superoxide $\left(\mathrm{O}_{2}-\right)^{-}$radical scavenging activity of Ethyl acetate fraction of Streptomyces KAV 2 was measured on the basis of superoxide radical inhibition 31 . Various concentrations (10-60 $\mu \mathrm{g} / \mathrm{mL})$ of Ethyl acetate fraction were mixed with $50 \mathrm{mM}$ phosphate buffer (pH-7.6). The mixtures were combined with $200 \mu \mathrm{L}$ of $1.5 \mathrm{mM}$ Riboflavin, $200 \mu \mathrm{L}$ of $12 \mathrm{mM}$ EDTA followed by $100 \mu \mathrm{L}$ of $50 \mathrm{mM}$ NBT. The reaction was started by illuminating the test tubes in UVlamp for $15 \mathrm{~min}$. The superoxide $\left.\left(\mathrm{O}_{2}-\right)^{-}\right)$radical reduces NBT to a blue colored formazon can be measured at $590 \mathrm{~nm}$ using UV-vis spectrophotometer. Ascorbic acid was used as the standard reference. The percentage of superoxide $\left(\mathrm{O}_{2}-{ }^{-}\right)$ radical inhibition was calculated as:

$$
\% \text { of Superoxide }\left(\mathrm{O}_{2}-\right) \text { radical inhibition }=\left[\frac{\text { Control }- \text { Sample }}{\text { Control }}\right] * 100
$$

\section{$\mathrm{ABTS}^{\bullet}+$ radical cation scavenging activity}

The antioxidant capacity was estimated in terms of the $\mathrm{ABTS}^{\bullet}+$ radical cation scavenging activity following the procedure ${ }^{32}$. ABTS ${ }^{\circ}+$ was obtained by reacting $7 \mathrm{mM}$ ABTS stock solution with $2.45 \mathrm{mM}$ potassium persulfate and the mixture was left to stand in the dark at room temperature for $12-16 \mathrm{~h}$ before use. The $\mathrm{ABTS}^{\bullet}+$ solution (stable for 2 days) was diluted with distilled water to reach an absorbance of $0.70 \pm 0.02$ at $734 \mathrm{~nm}$. Various concentrations $(2-12 \mu \mathrm{g} / \mathrm{mL})$ of Ethyl acetate fraction of Streptomyces KAV 2 was mixed with $500 \mu \mathrm{L}$ of diluted $\mathrm{ABTS}^{\bullet+}$ solution and the absorbance was measured at $734 \mathrm{~nm}$ after $10 \mathrm{~min}$ using UVvis spectrophotometer. Ascorbic acid was used as the standard reference. The percentage of $\mathrm{ABTS}^{\bullet}+$ radical cation inhibition was calculated as:

$$
\% \text { of } \operatorname{ABTS}^{\bullet+} \text { radical cation inhibition }=\left[\frac{\text { Control }- \text { Sample }}{\text { Control }}\right] * 100
$$

\section{Phosphomolybdenum reduction activity}

The antioxidant capacity of Ethyl acetate fraction of Streptomyces KAV 2 was assessed by the method ${ }^{33}$. The Ethyl acetate fraction with different concentrations ranging from $20-120 \mu \mathrm{g} / \mathrm{mL}$ was combined with $1 \mathrm{~mL}$ of reagent solution containing ammonium molybdate $(4 \mathrm{mM})$, sodium phosphate $(28 \mathrm{mM})$ and sulphuric acid $(600 \mathrm{mM})$. The reaction mixture was incubated in water bath at $95^{\circ} \mathrm{C}$ for 90 min. The absorbance of the coloured complex was measured at $695 \mathrm{~nm}$ using UV-vis spectrophotometer. Ascorbic acid was used as the standard reference. The percentage of $\mathrm{Mo}^{6+}$ reduction was calculated as:

$$
\% \text { of } \mathrm{Mo}^{6+} \text { reduction }=\left[\frac{\text { Sample }- \text { Control }}{\text { Sample }}\right] * 100
$$

\section{Ferric $\left(\mathrm{Fe}^{3+}\right)$ reducing power activity}

The reducing power of Ethyl acetate fraction of Streptomyces KAV 2 was determined by slightly modified method ${ }^{34}$. One $\mathrm{mL}$ of Ethyl acetate fraction in different concentrations (20$120 \mu \mathrm{g} / \mathrm{mL}$ ) was mixed with $1 \mathrm{~mL}$ of potassium ferricyanide $\left[\mathrm{K}_{3} \mathrm{Fe}(\mathrm{CN})_{6}\right](1 \%, \mathrm{w} / \mathrm{v})$ solution and $1 \mathrm{~mL}$ of $0.2 \mathrm{M}$ phosphate buffer (pH 6.6) solution. The mixture was then incubated at $50^{\circ} \mathrm{C}$ for $30 \mathrm{~min}$ in water bath. Five hundred $\mu \mathrm{L}$ of trichloroacetic acid $(10 \% \mathrm{w} / \mathrm{v})$ was added to each mixture. Then $100 \mu \mathrm{L}$ of freshly prepared Ferric chloride $(0.1 \%, \mathrm{w} / \mathrm{v})$ solution was added and the absorbance was measured at $700 \mathrm{~nm}$ using UV-vis spectrophotometer. Ascorbic acid was used as the standard reference. The percentage of $\mathrm{Fe}^{3+}$ reduction was calculated as:

$$
\% \text { of } \mathrm{Fe}^{3+} \text { reduction }=\left[\frac{\text { Sample }- \text { Control }}{\text { Sample }}\right] * 100
$$

\section{Qualitative analysis of bioactive compounds}

Qualitative analysis for the Ethyl acetate fraction of Streptomyces KAV 2 was performed in order to find out the classes or nature of antimicrobial compounds group ${ }^{35}$ such as phenols, alkaloids, terpenoids, steroids, flavonoids, etc..

\section{Quantitative analysis - Determination of total phenols and flavonoids}

\section{Total phenolic content}

Folin-Ciocalteau reagent method was used to determine the total phenolic compounds with slight modifications ${ }^{36}$. One hundred $\mu \mathrm{L}$ of Ethyl acetate fraction of Streptomyces KAV 2 was mixed with $900 \mu \mathrm{L}$ of methanol and $1 \mathrm{~mL}$ of Folin Ciocalteau reagent (1:10 diluted with distilled water). After $5 \mathrm{~min}, 1 \mathrm{~mL}$ of $20 \%\left(\mathrm{w} / \mathrm{v}\right.$ ) $\mathrm{Na}_{2} \mathrm{CO}_{3}$ solution was added. The mixture was then allowed to stand for $30 \mathrm{~min}$ incubation in dark at room temperature. The absorbance was measured at $765 \mathrm{~nm}$ using UV-vis spectrophotometer. The total phenolic content was expressed in terms of gallic acid equivalent $(\mu \mathrm{g} / \mathrm{mg}$ of extract), which is a common reference compound.

\section{Total flavonoids content}

The total flavonoid content of Ethyl acetate fraction of Streptomyces KAV 2 was determined using aluminium chloride reagent method with slight modifications ${ }^{37}$. Five hundred $\mu \mathrm{L}$ of Ethyl acetate fraction was mixed with $500 \mu \mathrm{L}$ of methanol and $0.5 \mathrm{~mL}$ of $5 \%(\mathrm{w} / \mathrm{v})$ sodium nitrite solution. Then, $0.5 \mathrm{~mL}$ of $10 \%(\mathrm{w} / \mathrm{v})$ aluminium chloride solution was added and incubated for $5 \mathrm{~min}$ at room temperature followed by $100 \mu \mathrm{L}$ of $1 \mathrm{M} \mathrm{NaOH}$ solution was added. Absorbance was measured at $510 \mathrm{~nm}$ using UV-vis spectrophotometer. The total flavonoid content was expressed in terms of quercetin equivalent $(\mu \mathrm{g} / \mathrm{mg}$ of extract), which is a common reference compound.

\section{Thin layer chromatographic analysis}

The Ethyl acetate fraction of Streptomyces KAV 2 were spotted on the baseline of the silica gel plates (stationary phase) at $1 \mathrm{~cm}$ and then allowed to dry at room temperature. The plates were placed in TLC chamber pre-saturated with the mobile phase as Toluene: Ethyl acetate: Methanol (solvent) in the ratio 1:0.8:0.2. The chromatogram was developed and visualized under UV light and in the iodine chamber, and then the spots were marked 38 . The Rf values were calculated.

$R_{f}$ value $=$ Distance travelled by the solute $/$ Distance travelled by the solvent

\section{Antibacterial activity for the Ethyl acetate fraction of Streptomyces KAV 2 by Agar Disc diffusion method}

Mueller Hinton agar was prepared and poured in the sterile petri dishes and allowed to solidify. 24 hours grown bacterial pathogens such as S.aureus, M.luteus, B.subtilis, S.flexneri, E.coli and P.vulgaris were swabbed on Mueller Hinton agar plates ${ }^{39}$. Sterile discs were placed over the surface of agar plates. Three concentrations $(200 \mu \mathrm{g}, 250 \mu \mathrm{g}$ and $300 \mu \mathrm{g}$ ) of Ethyl acetate fraction of Streptomyces KAV 2 were loaded in the sterile disc respectively. Dimethyl sulphoxide was used as solvent control and Azithromycin was preferred as positive control. Azithromycin belongs to the class of drugs known as macrolide antibiotics. The plates 
were then incubated at $37^{\circ} \mathrm{C}$ for 24 hours and after incubation the inhibition diameter was measured using zone scale.

\section{Gas chromatography-Mass Spectrometry (GC-MS) analysis}

For GC-MS analysis, the Ethyl acetate fraction of Streptomyces KAV 2 were injected into a HP-5 column $(30 \mathrm{~m}$ $\mathrm{X} 0.25 \mathrm{~mm}$ i.d with $0.25 \mu \mathrm{m}$ film thickness), Agilent technologies $6890 \mathrm{~N}$ JEOL GC Mate II GC-MS model. Following chromatographic conditions were used: Helium as carrier gas, flow rate of $1 \mathrm{~mL} / \mathrm{min}$; and the injector was operated at $200^{\circ} \mathrm{C}$ and column oven temperature was programmed as $50-250^{\circ} \mathrm{C}$ at a rate of $10^{\circ} \mathrm{C} / \mathrm{min}$ injection mode. Following MS conditions were used: ionization voltage of $70 \mathrm{eV}$; ion source temperature of $250^{\circ} \mathrm{C}$; interface temperature of $250^{\circ} \mathrm{C}$; mass range of 50-600 mass units 40 .

\section{Identification of components}

The database of National Institute Standard and Technology (NIST) having more than 62,000 patterns was used for the interpretation on mass spectrum of GC-MS. The mass spectrum of the unknown component was compared with the spectrum of the known components stored in the NIST library.

\section{Statistical analysis}

All the experiments were conducted in triplicates and data given in tables were average of three replicates. All data were reported as the mean \pm standard deviation of three replicates.

\section{RESULTS AND DISCUSSION}

Actinomycetes grew not before 4 days of incubation at $28^{\circ} \mathrm{C}$ and once isolated, they grew fast as pure cultures. The substrate mycelium could be observed developing within 48 hours (Table 1). The appearance of colonies between $2^{\text {nd }}$ to $4^{\text {th }}$ days seems to be like a typical bacterial colony. This is because of the formation of substrate and aerial mycelia but no sporulation. Confirmation of an actinomycetal colony can be done by observing the leathery texture of the colony (Figure 1 and 2). The colonies are tightly held on the agar surface like a plant on the soil surface.

Table 1: Observation of actinomycetes colonies on Starch casein agar plates

\begin{tabular}{|c|c|c|}
\hline \multicolumn{2}{|c|}{$\begin{array}{c}\text { GROWTH } \\
\text { OBSERVATION }\end{array}$} & Piper betle rhizosphere soil \\
\hline \multirow{4}{*}{ DAY 1 } & Dilution & Number of Colonies \\
\cline { 2 - 3 } & $10^{-2}$ & 18 \\
\cline { 2 - 3 } & $10^{-4}$ & 0 \\
\cline { 2 - 3 } & $10^{-6}$ & 2 \\
\hline \multirow{3}{*}{ DAY 4 } & $10^{-8}$ & 1 \\
\cline { 2 - 3 } & $10^{-2}$ & 22 \\
\cline { 2 - 3 } & $10^{-4}$ & 2 \\
\cline { 2 - 3 } & $10^{-6}$ & 8 \\
\cline { 2 - 3 } & $10^{-8}$ & 1 \\
\hline
\end{tabular}
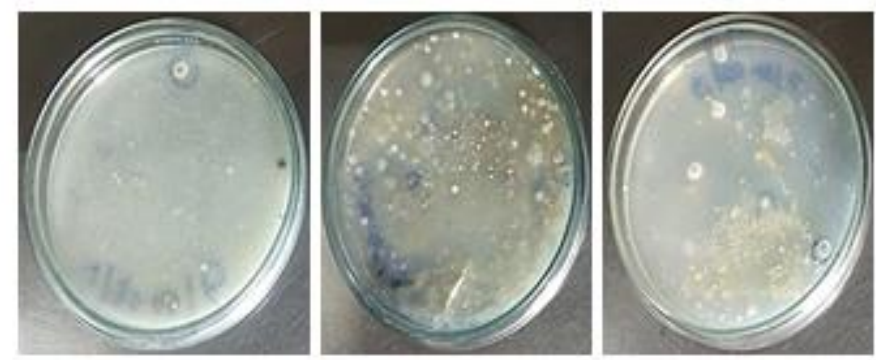

Figure.1: Colonies observation on Starch casein agar plates

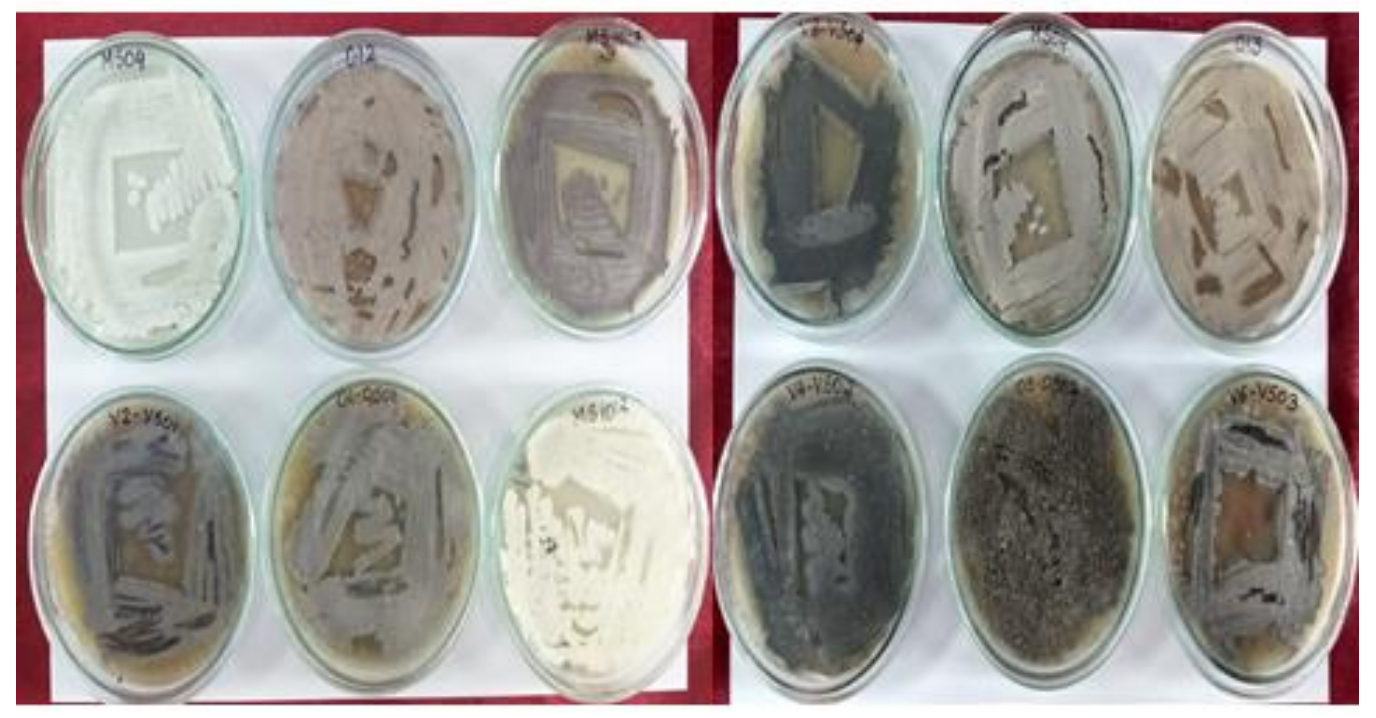

Figure.2: Actinomycetal isolates by sub-culturing method

\section{Colony Morphology-Aerial spore mass appearance and Pigmentation}

The collection of isolates was diverse with respect to growth pattern, aerial and substrate hyphae, colony margin and pigments. The isolates produced a range of aerial mycelium and substrate mycelium such as grey, sandal, white, peach, pale yellow and brown. The colonies as texture were powdery, smoothy, chalky in nature and the colony margin appeared to be webbed colonies and depression on top of colony (Table 2). Majority of the isolated strains produced the earthy odour of Geosmin, which is an predominant antibiotic produced by Streptomyces group. 
Table 2: Characteristic features of actinomycetal isolates

\begin{tabular}{|c|c|c|c|c|c|}
\hline S.No & Isolate & $\begin{array}{c}\text { Aerial } \\
\text { mycelium }\end{array}$ & $\begin{array}{c}\text { Substrate } \\
\text { mycelium }\end{array}$ & $\begin{array}{c}\text { Texture, } \\
\text { Colony Margin }\end{array}$ & $\begin{array}{c}\text { Diffusible } \\
\text { pigmentation }\end{array}$ \\
\hline 1 & VS 01 & Grey & Peachish green & Chalky, Depression on top of colony & Peach \\
\hline 2 & VS 02 & Green & $\begin{array}{c}\text { Yellowish } \\
\text { green }\end{array}$ & Smoothy, Dew drops on top of colony & Peach \\
\hline 3 & VS 03 & Grey & Dark grey & Chalky, Webbed colonies & Peach \\
\hline 4 & KAV 2 & Dark grey & Peach & Powdery, Dew drops on top of colony & Peach \\
\hline 5 & OS 01 & Whitish grey & Peachish green & Powdery, Depression on top of colony & Sandal \\
\hline 6 & OS 02 & Whitish grey & Dark green & Chalky, Depression on top of colony & Sandal \\
\hline 7 & OS 03 & White & Peach & Chalky, Depression on top of colony & Creamy sandal \\
\hline 8 & 013 & Sandal & Brown & Chalky, Depression on top of colony & Creamy sandal \\
\hline 9 & 012 & White & Pale yellow & Chalky, Webbed & Light brown \\
\hline 10 & MS 10-2 & White & Pale yellow & Powdery, Webbed colonies & Nil \\
\hline 11 & MS $10^{-7}$ & Grey & Light brown & Chalky, Webbed colonies & Light sandal \\
\hline 12 & MS 04 & Peach & Brown & Chalky, Depression on top of colony & Sandal \\
\hline
\end{tabular}

The bioactive compound was dissolved completely in mid polar solvent, ethyl acetate followed by re-dissolving it in methanol to evaluate antioxidant and antibacterial ability. An antibiotic identification can be achieved based on its antimicrobial spectrum, ionic character and behaviour on chromatographic plates. According to the description given in Bergey's Manual of Systemic Bacteriology, the selected actinomycete strain belongs to Streptomyces group.

\section{In vitro Antioxidant activities of Ethyl acetate fraction of Streptomyces KAV 2}

\section{DPPH“ radical scavenging activity}

DPPH is one of the few stable and commercially available organic nitrogen radicals. Substances which are able to perform this reaction can be considered as antioxidants and therefore radical scavengers. The ability of Ethyl acetate fraction of Streptomyces KAV 2 to scavenge free radicals formed was assessed using 1,1-diphenyl-2-picrylhydrazyl radical (DPPH). The Ethyl acetate fraction of Streptomyces KAV 2 demonstrated high capacity for scavenging free radicals by reducing the stable DPPH (1,1-diphenyl-2- picryl hydrazyl) radical to the yellow coloured 1,1-diphenyl-2picrylhydrazine and the reducing capacity increased with increasing concentration of the bioactive compounds ${ }^{41}$. The maximum DPPH radical scavenging activity of Ethyl acetate fraction of Streptomyces KAV 2 was $94.84 \pm 0.24 \%$ at 60 $\mu \mathrm{g} / \mathrm{mL}$ concentration (Table 3 ). The $\mathrm{IC}_{50}$ value for Ethyl acetate fraction of Streptomyces KAV 2 was found to be 26.91 $\mu \mathrm{g} / \mathrm{mL}$ concentration (Graph 1) and was compared with standard (Ascorbic acid, IC $\mathrm{I}_{50}=11.18 \mu \mathrm{g} / \mathrm{mL}$ concentration).

\section{Superoxide $\left(\mathrm{O}_{2}--\right)$ radical scavenging activity}

Superoxide is biologically quite toxic and is deployed by the immune system to kill invading microorganisms. It is an oxygen-centred radical with selective reactivity. It also produced by a number of enzyme systems in transfers that univalently reduce molecular oxygen. The biological toxicity of superoxide is due to its capacity to inactivate iron-sulfur cluster containing enzymes, which are critical in a wide variety of metabolic pathways, thereby liberating free iron in the cell, which can undergo Fenton chemistry and generate the highly reactive hydroxyl radical. It can also reduce certain iron complex such as cytochrome c.

Superoxide anion is also very harmful to cellular components and their effects can be magnified because it produces other kinds of free radicals and oxidizing agents. Flavonoids are effective antioxidants, mainly because they scavenge superoxide anions. Superoxide anions derived from dissolved oxygen by the riboflavin-light-NBT system will reduce NBT in this system. In this method, superoxide anion reduces the yellow dye $\left(\mathrm{NBT}^{2+}\right)$ to blue formazan, which is measured at $590 \mathrm{~nm}$ in UV-Vis spectrophotometer. Antioxidants are able to inhibit the blue NBT formation and the decrease of absorbance with antioxidants indicates the consumption of superoxide anion in the reaction mixture 42 . The maximum superoxide $\left(\mathrm{O}_{2}-\right)$ radical scavenging activity of Ethyl acetate fraction of Streptomyces KAV 2 was $62.88 \pm 0.42 \%$ at $60 \mu \mathrm{g} / \mathrm{mL}$ concentration. (Table 3 and Graph 1) and the $\mathrm{IC}_{50}$ value for the Ethyl acetate fraction of Streptomyces KAV 2 was found to be $41.72 \mu \mathrm{g} / \mathrm{mL}$ concentration. It was compared with the standard of ascorbic acid ( $\mathrm{IC}_{50}=12.39 \mu \mathrm{g} / \mathrm{mL}$ concentration).

Table 3: DPPH' radical and Superoxide $\left(\mathrm{O}_{2--}\right)$ radical scavenging activities of

Ethyl acetate fraction of Streptomyces KAV 2

\begin{tabular}{|c|c|c|c|}
\hline S.No & $\begin{array}{c}\text { Concentration } \\
(\boldsymbol{\mu g} / \mathbf{m L})\end{array}$ & \multicolumn{2}{|c|}{ Percentage of radical scavenging activity* } \\
\cline { 3 - 4 } & 10 & DPPH radical & Superoxide $\left(\mathbf{O}_{2}-\mathbf{-}\right)$ radical \\
\hline 1 & 20 & $28.96 \pm 0.45$ & $18.54 \pm 0.32$ \\
\hline 2 & 30 & $35.95 \pm 0.50$ & $29.48 \pm 0.43$ \\
\hline 3 & 40 & $55.73 \pm 0.28$ & $36.19 \pm 0.28$ \\
\hline 4 & 50 & $60.24 \pm 0.53$ & $47.93 \pm 0.31$ \\
\hline 5 & 60 & $84.13 \pm 0.49$ & $54.26 \pm 0.37$ \\
\hline 6 & $94.84 \pm 0.24$ & $62.88 \pm 0.42$ \\
\hline 7 & IC $_{\mathbf{5 0}}$ value & $\mathbf{2 6 . 9 1} \boldsymbol{\mu g} / \mathbf{m L}$ & $\mathbf{4 1 . 7 2} \boldsymbol{\mu g} / \mathbf{m L}$ \\
\hline
\end{tabular}

(*Average value of triplicates) 


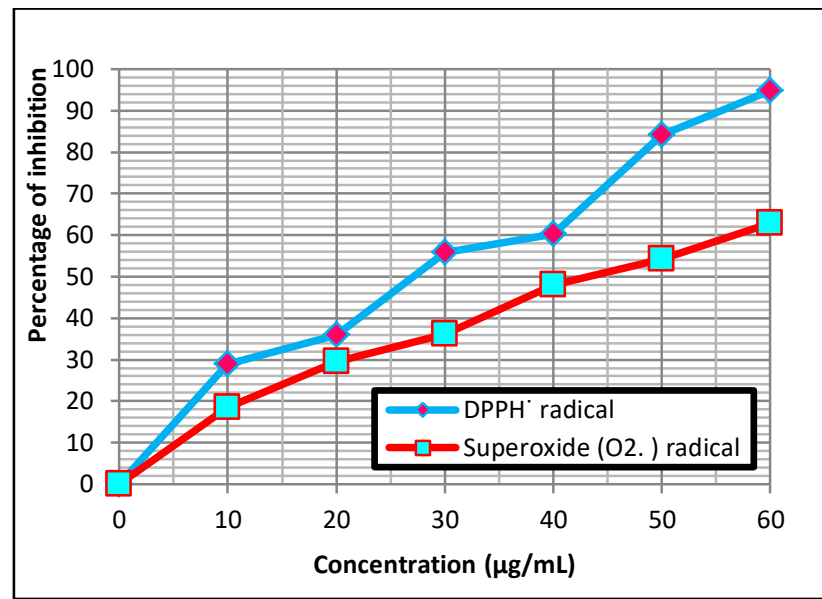

Graph 1: DPPH'radical and Superoxide ( $\left.\mathrm{O}_{2}-\mathrm{-}\right)$ radical scavenging activities of Ethyl acetate fraction of Streptomyces KAV 2

\section{$\mathrm{ABTS}^{\bullet}+$ radical cation scavenging activity}

The ABTS method uses ABTS radicals performed by oxidation of ABTS with potassium persulphate and this method becomes time consuming in terms of waiting for the ABTS radicals to be generated as it takes around 12-16 hours for the reaction of ABTS with potassium persulphate. ABTS $^{*+}$ is a blue chromophore produced by the reaction between ABTS and potassium persulfate and ABTS•+ radical cation gets reduced in the presence of active compounds and the remaining radical cation concentration was then quantified at $734 \mathrm{~nm}$. It can be prepared using $\mathrm{K}_{2} \mathrm{~S}_{2} \mathrm{O}_{8}$ as an oxidant. The blue-green colour of ABTS solution is formed by the loss of an electron by the nitrogen atom of ABTS $(2,2$ azinobis (3ethylbenzothiazolin-6-sulfonic acid)).

Table 4: $\mathrm{ABTS}^{\bullet}+$ radical cation scavenging activity of

Ethyl acetate fraction of Streptomyces KAV 2

\begin{tabular}{|c|c|c|}
\hline S.No & $\begin{array}{c}\text { Concentration } \\
(\boldsymbol{\mu g} / \mathbf{m L})\end{array}$ & $\begin{array}{c}\text { Percentage of } \\
\text { inhibition* }\end{array}$ \\
\cline { 3 - 3 } & & ABTS $^{\bullet}{ }^{+}$radical cation \\
\hline 1 & 2 & $34.60 \pm 0.40$ \\
\hline 2 & 4 & $46.96 \pm 0.27$ \\
\hline 3 & 6 & $55.06 \pm 0.13$ \\
\hline 4 & 8 & $67.06 \pm 0.35$ \\
\hline 5 & 10 & $74.70 \pm 0.10$ \\
\hline 6 & 12 & $82.46 \pm 0.45$ \\
\hline 7 & IC $_{50}$ value & $\mathbf{4 . 2 5} \boldsymbol{\mu g} / \mathbf{m L}$ \\
\hline
\end{tabular}

(*Average value of triplicates)

The decolourization of the solution takes place in the presence of hydrogen donating antioxidant (nitrogen atom quenches the hydrogen atom ${ }^{43}$. The maximum ABTS•+ radical cation scavenging activity of Ethyl acetate fraction of Streptomyces KAV 2 was $82.46 \pm 0.45 \%$ at $12 \mu \mathrm{g} / \mathrm{mL}$ concentration (Table 4) and the $\mathrm{IC}_{50}$ value for the Ethyl acetate fraction of Streptomyces KAV 2 was found to be as $4.25 \mu \mathrm{g} / \mathrm{mL}$ concentration, which was compared with standard ascorbic acid ( IC $_{50}=3.84 \mu \mathrm{g} / \mathrm{mL}$ concentration) (Graph 2).

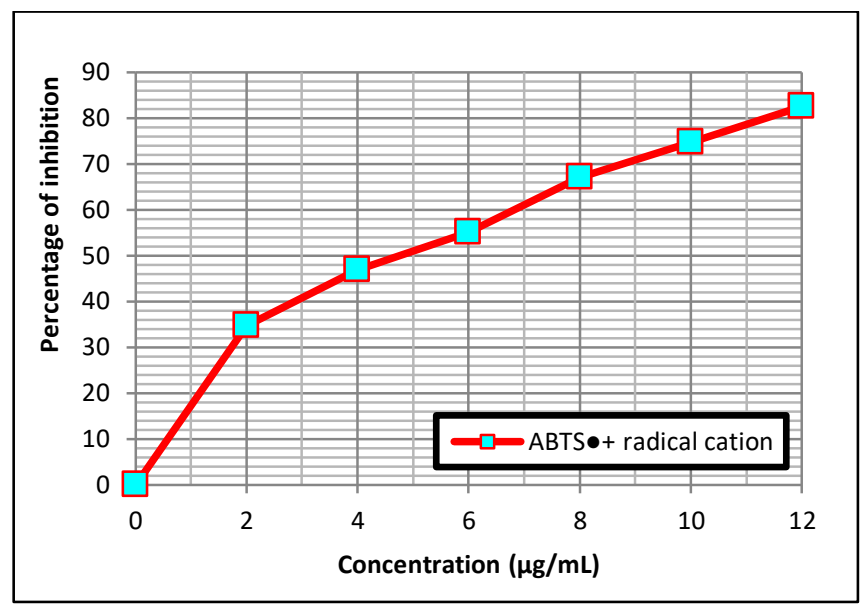

Graph 2: $\mathrm{ABTS}^{\bullet}+$ radical cation scavenging activity of Ethyl acetate fraction of Streptomyces KAV 2

\section{Phosphomolybdenum reduction activity}

The total antioxidant activity of Ethyl acetate fraction of Streptomyces KAV 2 was measured spectrophotometrically by phosphomolybdenum reduction method, which is based on the reduction of Mo (VI) to Mo (V) by the formation of green phosphate/Mo (V) complex at acidic $\mathrm{pH}$, with a maximum absorption at $695 \mathrm{~nm}^{44}$. The maximum phosphomolybdenum reduction of Ethyl acetate fraction of Streptomyces KAV 2 was $89.53 \pm 0.55 \%$ at $120 \mu \mathrm{g} / \mathrm{mL}$ concentration with the $\mathrm{RC}_{50}$ of $32.08 \mu \mathrm{g} / \mathrm{mL}$ concentration (Table 5 and Graph 3). It was compared with the standard ascorbic acid $\left(\mathrm{RC}_{50}=9.69 \mu \mathrm{g} / \mathrm{mL}\right)$.

\section{Ferric $\left(\mathrm{Fe}^{3+}\right)$ reducing power activity}

Fe (III) reduction is often used as an indicator of electron donating activity, which is an important mechanism of phenolic antioxidant action. The reducing ability of a compound generally depends on the presence of reductones (antioxidants), which exert the antioxidant activity by stopping the free radical chain by hydrogen atom donation ${ }^{45,46}$. The antioxidant molecules present in the ethyl acetate fraction of Streptomyces KAV 2 caused the reduction of $\mathrm{Fe}^{3+}$ / ferricyanide complex to the ferrous form and thus proved the reducing power ability.

Table 5: Phosphomolybdenum reduction and $\mathrm{Fe}^{3+}$ reduction activities of

Ethyl acetate fraction of Streptomyces KAV 2

\begin{tabular}{|c|c|c|c|}
\hline \multirow[t]{2}{*}{ S.No } & \multirow{2}{*}{$\begin{array}{l}\text { Concentration } \\
(\mu \mathrm{g} / \mathrm{mL})\end{array}$} & \multicolumn{2}{|c|}{ Percentage of reduction* } \\
\hline & & $\mathrm{Mo}^{6+}$ reduction & $\mathrm{Fe}^{3+}$ reduction \\
\hline 1 & 20 & $12.36 \pm 0.41$ & $12.83 \pm 0.50$ \\
\hline 2 & 40 & $62.33 \pm 0.45$ & $20.60 \pm 0.17$ \\
\hline 3 & 60 & $82.06 \pm 0.40$ & $56.43 \pm 0.28$ \\
\hline 4 & 80 & $86.56 \pm 0.32$ & $58.9 \pm 0.40$ \\
\hline 5 & 100 & $88.96 \pm 0.45$ & $78.76 \pm 0.10$ \\
\hline 6 & 120 & $89.53 \pm 0.55$ & $81.83 \pm 0.48$ \\
\hline 7 & $\mathrm{RC}_{50}$ value & $32.08 \mu \mathrm{g} / \mathrm{mL}$ & $53.16 \mu \mathrm{g} / \mathrm{mL}$ \\
\hline
\end{tabular}

(*Average value of triplicates) 


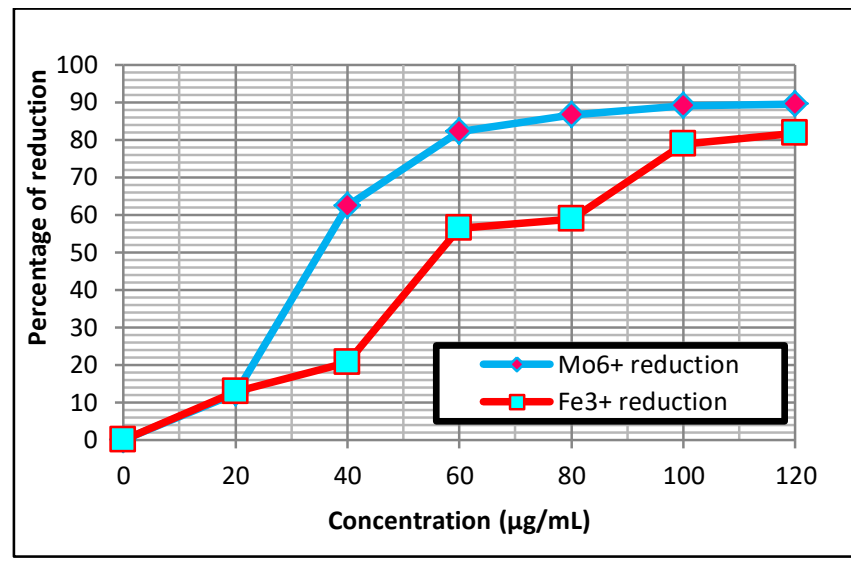

Graph 3: Phosphomolybdenum reduction and $\mathrm{Fe}^{3+}$ reduction activities of Ethyl acetate fraction of Streptomyces KAV 2

The reducing power of $\mathrm{Fe}^{3+}$ to $\mathrm{Fe}^{2+}$ by Ethyl acetate fraction of Streptomyces KAV 2 was studied and showed reduction ability in a dose dependent manner ${ }^{47}$. The maximum reduction of Ethyl acetate fraction of Streptomyces KAV 2 was $81.83 \pm 0.48 \%$ at $120 \mu \mathrm{g} / \mathrm{mL}$ concentration (Table 5 and Graph 3). The $\mathrm{RC}_{50}$ value for Ethyl acetate fraction of Streptomyces KAV 2 was found to be $53.16 \mu \mathrm{g} / \mathrm{mL}$ concentration and was compared with the standard $(22.50$ $\mu \mathrm{g} / \mathrm{mL}$ concentration) Ascorbic acid.

\section{Qualitative analysis of bioactive compounds}

Qualitative screening was detected to study the nature of the compound resulting in various reactions. Various tests such as lead acetate test for tannins, Salkowski test for terpenoids, Liebermann-Burchard test for steroids (Table 6) gave positive results for the Ethyl acetate fraction of Streptomyces KAV 2.

Table 6: Qualitative analysis of Ethyl acetate fraction of Streptomyces KAV 2

\begin{tabular}{|c|c|c|}
\hline S.No & Test name & Results \\
\hline \multirow{2}{*}{1} & Alkaloids & \\
\cline { 2 - 3 } & (a)Hager's test & +++ \\
\cline { 3 - 3 } & (b)Wagner's test & +++ \\
\hline 2 & Phenols & +++ \\
\hline 3 & Flavonoids & +++ \\
\hline 4 & Tannins & +++ \\
\hline 5 & Saponins & --- \\
\hline 6 & Terpenoids & +++ \\
\hline 7 & Glycosides & --- \\
\hline 8 & Carbohydrates & +++ \\
\hline 9 & Steroids & +++ \\
\hline
\end{tabular}

\section{Determination of total phenols and flavonoids}

Phenolic hydroxyl groups are good hydrogen donors: hydrogen-donating antioxidants can react with reactive oxygen and reactive nitrogen species in a termination reaction, which breaks the generation cycle of new radicals. Following interaction with the initial reactive species, a radical form of the antioxidant is produced, having a much greater chemical stability than the initial radical $48-54$. The interaction of the hydroxyl groups of phenolics with the $\pi$ electrons of the benzene ring gives the molecules special properties, most notably the ability to generate free radicals where the radical is stabilized by delocalization. The formation of these relatively long-lived radicals is able to modify radical-mediated oxidation processes ${ }^{55}$.
Phenolic structures often have the potential to strongly interact with proteins, due to their hydrophobic benzenoid rings and hydrogen-bonding potential of the phenolic hydroxyl groups. This allows phenolic compounds the ability to act as antioxidants also by virtue of their capacity to inhibit some enzymes involved in radical generation, such as various cytochrome P450 isoforms, lipoxygenases, cyclooxygenase and xanthine oxidase ${ }^{55,56 .}$

Flavonoids possess many biological properties such as antiinflammatory, oestrogenic, enzyme inhibition, antimicrobial, antiallergic, vascular and cytotoxic antitumour activity 57. Antioxidant activity of flavonoids is also responsible for other biological activities in which the oxidative stress prevention is beneficial. For example, the anticancer activity of some compounds is due to their ability to scavenge free radicals, thus avoiding the early stages of cancer promotion. Besides this mechanism, flavonoids have also been reported to act as anticancer agents via regulation of signal transduction pathways of cell growth and proliferation, oncogenes suppression and tumor formation, induction of apoptosis, modulation of enzyme activity related to detoxification, oxidation and reduction, stimulation of the immune system and DNA repair, and regulation of hormone metabolism ${ }^{58,59}$ (Table 7).

Table 7: Determination of total phenols and flavonoids content of Ethyl acetate fraction of Streptomyces KAV 2

\begin{tabular}{|c|c|c|}
\hline S.No & Biochemical Parameters & Amount $(\boldsymbol{\mu g} / \mathbf{m g})^{*}$ \\
\hline 1 & Phenols & $707.07 \pm 0.14 \mathrm{GAE}$ \\
\hline 2 & Flavonoids & $43.05 \pm 0.15 \mathrm{QE}$ \\
\hline
\end{tabular}

(*Average value of 3 replicates)

\section{Thin layer chromatographic analysis}

Thin layer chromatography analysis was carried out for the Ethyl acetate fraction in the solvent system of Toluene: Ethyl acetate: Methanol (Figure 3) in the ratio 1:0.8:0.2.

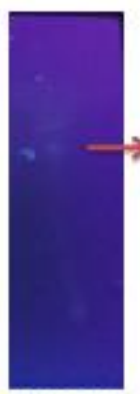

UV light

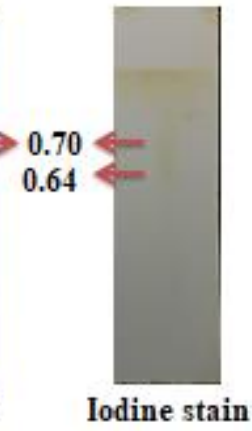

Iodine stain
Figure.3: Thin layer chromatography of Ethyl acetate fraction of Streptomyces KAV 2

Analytical TLC plays active role in the detection and monitoring of compounds through separation process. Effective visualization or detection is crucial to obtain pure compounds. Ultraviolet exposure, spray detection with various reagents and exposure to Iodine vapour are the three common methods for detection of bioactive compound on TLC plate. The use of iodine as vapour enables the detection of separated substances rapidly and economically before final characterization with a group specific reagent. Where lipophilic zones are present on a silica gel layer, the iodine molecules will concentrate in the substance zones giving chromatographic zones in brown colour on a yellow background 60 . 
Antibacterial activity for the Ethyl acetate fraction of Streptomyces KAV 2 by Agar Disc diffusion method

Antibiotics essentially target structures or functions of bacteria, such as cell wall biosynthesis, translation, RNA transcription, DNA replication, etc. Actinomycetes are composed of glycosylated cyclic or polycyclic non-ribosomal peptides. Glycopeptides bind to the dipeptide D-alanyl--Dalanine (D-Ala-D-Ala) within the cell wall of Gram-positive bacteria preventing the addition of new units to the peptidoglycan and inhibiting the peptidoglycan synthesis 61.

Table 8: Antibacterial activity of Ethyl acetate fraction of Streptomyces KAV 2

by agar disc diffusion method

\begin{tabular}{|c|c|c|c|c|c|}
\hline \multirow{2}{*}{ S.No } & \multirow{2}{*}{ Test pathogens } & \multicolumn{4}{|c|}{ Zone of inhibition (mm) } \\
\cline { 3 - 6 } & & Standard $(\mathbf{3 0} \boldsymbol{\mu g} / \mathbf{m L})$ & $\mathbf{2 0 0} \boldsymbol{\mu g} / \mathbf{m L}$ & $\mathbf{2 5 0} \boldsymbol{\mu g} / \mathbf{m L}$ & $\mathbf{3 0 0} \boldsymbol{\mu g} / \mathbf{m L}$ \\
\hline 1 & S.aureus & 18 & --- & 13 & 18 \\
\hline 2 & M.luteus & 15 & 11 & 16 & 19 \\
\hline 3 & B.subtilis & 27 & Below 10 & 10.5 & 19 \\
\hline 4 & S.flexneri & 26 & --- & 14 & 18 \\
\hline 5 & E.coli & 15.5 & Below 10 & Below 10 & 14 \\
\hline 6 & P.vulgaris & 26 & & & 10 \\
\hline
\end{tabular}
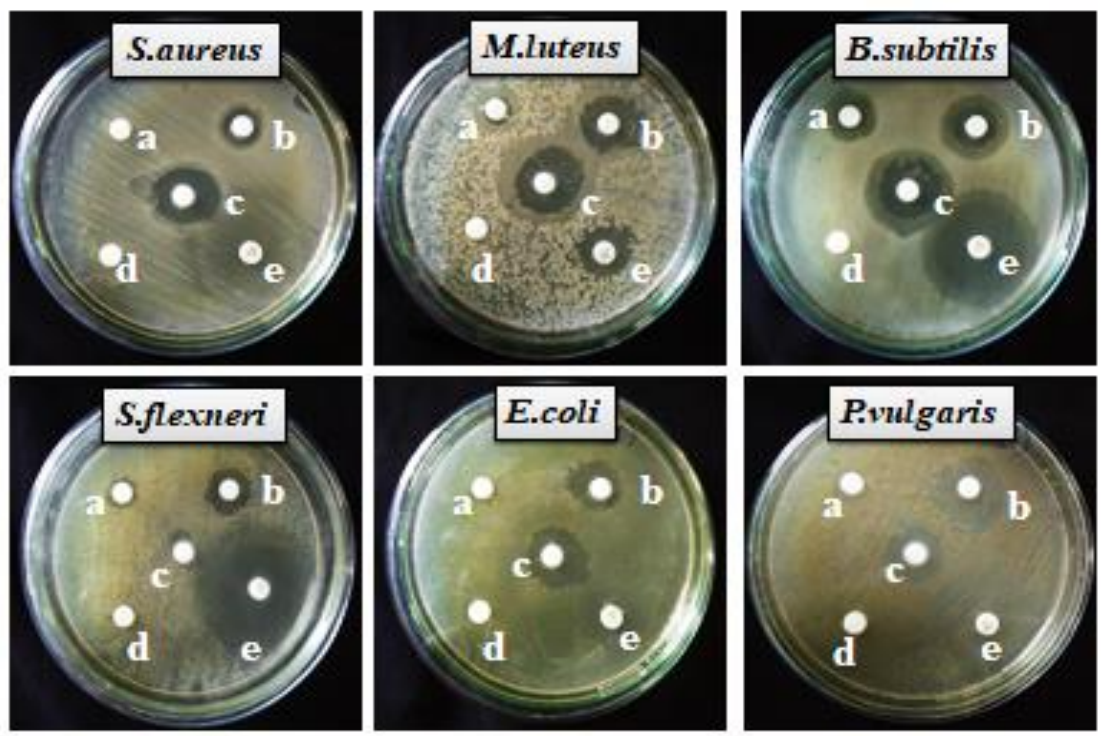

Concentration range of Ethyl acetate fraction of

Streptomyces KAV 2:

a-200 $\mu \mathrm{g} / \mathrm{mL}$, b-250 $\mu \mathrm{g} / \mathrm{mL}, \mathrm{c}-300 \mu \mathrm{g} / \mathrm{mL}$

d-Control-Dimethyl Sulphoxide

e-30 $\mu \mathrm{g} / \mathrm{mL}-$ Standard (Azithromycin)

Figure.4: Antibacterial activity of Ethyl acetate fraction of Streptomyces KAV 2 by agar disc diffusion method

The antibacterial activity for Ethyl acetate fraction of Streptomyces KAV 2 was performed against selected gram positive (Staphylococcus aureus, Micrococcus luteus, Bacillus subtilis) and gram negative (Shigella flexneri, Escherichia coli, Proteus vulgaris) bacterial pathogens. The maximum inhibitory effect was observed as $19 \mathrm{~mm}$ against Micrococcus luteus and Bacillus subtilis (Table 8) and the minimum inhibitory effect was observed as $14 \mathrm{~mm}$ against Shigella flexneri and Proteus vulgaris (Figure 4). Azithromycin inhibit protein synthesis and they impair the elongation cycle of the peptidyl chain by specifically binding to the $50 \mathrm{~S}$ subunit of the ribosome. Phospholipoidal cell membranes having a consequence of increasing the permeability process as well as loss of cellular constituents, enzymatic damage are involved in the cellular energy production of cellular energy, structural components synthesis and genetic material inactivation.

\section{Gas chromatography-Mass Spectrometry (GC-MS)} analysis

GC-MS is an analytical technique used for many applications which has very high sensitivity and specificity. In recent years GC-MS studies have been increasingly applied for the analysis of biomolecules as this technique has proved to be a valuable method for the analysis of nonpolar components and volatile essential oil, fatty acids, lipids and alkaloids. GCMS analysis plays a vital role as an analytical technique for quality control and standardization of bioactive molecules (Table 9 and Graph 4). The active principles with their Retention time (RT), Molecular formula and Molecular weight (MW) were recorded along with therapeutic applications ${ }^{62,63,64}$ (Table 10). 
Table 9: Gas chromatography-Mass Spectrometry of Ethyl acetate fraction of Streptomyces KAV 2

\begin{tabular}{|c|c|c|c|c|c|}
\hline S.NO & COMPOUND NAME & RT & COMPOUND STRUCTURE & $\begin{array}{l}\text { MOLECULAR } \\
\text { WEIGHT }\end{array}$ & $\begin{array}{c}\text { MOLECULAR } \\
\text { FORMULA } \\
(\mathrm{g} / \mathrm{mol})\end{array}$ \\
\hline 1 & $\begin{array}{l}\text { 3-Cyclohexen-1- } \\
\text { ol,4-methyl-1-(1- } \\
\text { methylethyl)- }\end{array}$ & 13.9 & & 154 & $\mathrm{C}_{10} \mathrm{H}_{18} \mathrm{O}$ \\
\hline 2 & $\begin{array}{l}\text { 1-Penten-3-one,1- } \\
\text { (2,6,6-trimethyl-1- } \\
\text { cyclohexen-1-yl)- }\end{array}$ & 14.87 & & 206.78 & $\mathrm{C}_{14} \mathrm{H}_{22} \mathrm{O}$ \\
\hline 3 & Flavone & 15.95 & & 222 & $\underline{\mathrm{C}}_{15} \underline{\mathrm{H}}_{10} \underline{\mathrm{O}_{2}}$ \\
\hline 4 & $\begin{array}{l}\text { n-Hexadecanoic } \\
\text { acid }\end{array}$ & 16.6 & & 255.86 & $\underline{\mathrm{C}}_{16} \underline{\mathrm{H}_{32}} \underline{\mathrm{O}}_{2}$ \\
\hline 5 & $\begin{array}{l}\text { 10-Octadecenoic } \\
\text { acid, methyl ester }\end{array}$ & 17.52 & & 295.91 & $\underline{\mathrm{C}_{19}} \underline{\mathrm{H}}_{36} \underline{\mathrm{O}_{2}}$ \\
\hline 6 & $\begin{array}{l}\text { Octadecanoic acid, } \\
\text { methyl ester }\end{array}$ & 17.73 & & 297.84 & $\mathrm{C}_{19} \mathrm{H}_{38} \mathrm{O}_{2}$ \\
\hline 7 & Octadecanoic acid & 18.38 & & 283.86 & $\underline{\mathrm{C}}_{18} \underline{\mathrm{H}_{36}} \underline{\mathrm{O}_{2}}$ \\
\hline 8 & $\begin{array}{c}\text { 1,3,5-Triazine,2- } \\
\text { chloro-4-(4- } \\
\text { morpholyl)-6- } \\
\text { phenoxy- }\end{array}$ & 19.27 & & 175.57 & $\underline{\mathrm{C}}_{\underline{5}} \underline{\mathrm{H}}_{6} \underline{\mathrm{ClN}_{3}} \underline{\mathrm{O}}_{2}$ \\
\hline 9 & Oleic acid & 18.18 & & 282 & $\underline{\mathrm{C}}_{18} \underline{\mathrm{H}}_{34} \underline{\mathrm{O}}_{2}$ \\
\hline 10 & $\begin{array}{c}\text { Phenol,2,6-bis(1,1- } \\
\text { dimethylethyl)-4- } \\
\text { [(4-hydroxy-3,5- } \\
\text { dimethylphenyl)met } \\
\text { hyl]- }\end{array}$ & 23.32 & & 340.47 & $\underline{\mathrm{C}}_{23} \underline{\mathrm{H}_{32}} \underline{\mathrm{O}_{2}}$ \\
\hline 11 & Isopropyl stearate & 21.5 & & 326.50 & $\mathrm{C}_{21} \mathrm{H}_{42} \mathrm{O}_{2}$ \\
\hline 12 & $\begin{array}{c}\text { Coumarine, 3-[2-(1- } \\
\text { methyl-2- } \\
\text { imidazolylthio)-1- } \\
\text { oxoethyl]- }\end{array}$ & 20.15 & & 300 & $\underline{\mathrm{C}}_{15} \underline{\mathrm{H}}_{12} \underline{\mathrm{N}_{2}} \underline{\mathrm{O}}_{3} \underline{\mathrm{S}}$ \\
\hline
\end{tabular}




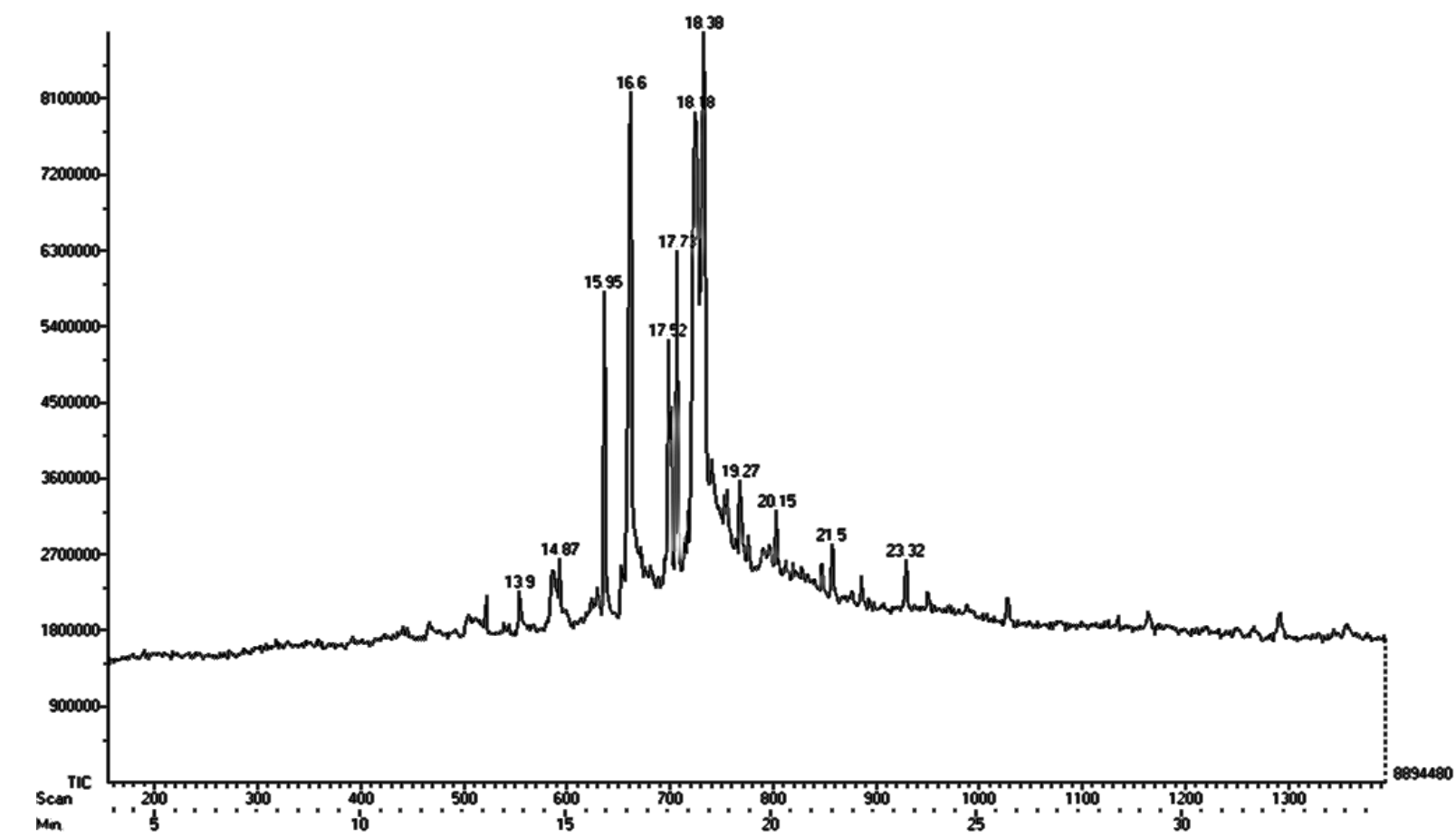

Graph 4: Gas chromatogram of Ethyl acetate fraction of Streptomyces KAV 2

Table 10: Pharmacological activity of Ethyl acetate fraction of Streptomyces KAV 2

\begin{tabular}{|c|c|c|}
\hline S.No & Compound Name and Structure & Pharmacological activity $65-70$ \\
\hline 1 & Flavone & $\begin{array}{l}\text { Production of Reactive Oxygen Species (ROS) can be } \\
\text { reduced by flavonoids. } \\
\text { Relevance of plant defense mode of action is highly } \\
\text { possible by flavonoids. } \\
\text { Formation of oxygen radicals can be prevented by } \\
\text { flavonoids thereby inhibiting the enzyme activity. }\end{array}$ \\
\hline 2 & noic acid & $\begin{array}{l}\text { Antioxidant activity } \\
\text { Nematicide } \\
\text { Pesticide } \\
\text { Lubricant } \\
\text { Antiandrogenic activity } \\
\text { Flavor } \\
\text { Hemolytic agent }\end{array}$ \\
\hline 3 & Oleic acid & $\begin{array}{l}5 \text { alpha reductase inhibitor } \\
\text { Hypocholestrolemic activity } \\
\text { Perfumery and flavour } \\
\text { Cancer preventing agent } \\
\text { Anti-inflammatory activity } \\
\text { Antibacterial activity }\end{array}$ \\
\hline 4 & Phenol, 2,4-bis(1,1-dimethylethyl)- & $\begin{array}{l}\text { Antimicrobial activity } \\
\text { Antioxidant activity } \\
\text { Antimalarial activity } \\
\text { Immuno-modulatory effect }\end{array}$ \\
\hline 5 & Isonronvl stor & $\begin{array}{l}\text { An emollient, skin conditioning agent, binder and } \\
\text { humectant activities. }\end{array}$ \\
\hline 6 & Coumarine, 3-[2-(1-methyl-2-imidazolylthio)-1-oxoethyl]- & $\begin{array}{l}\text { High Protein edema } \\
\text { Chronic Infections } \\
\text { Cancer treatment } \\
\text { Blood Coagulation and Anticoagulant } \\
\text { Inflammation }\end{array}$ \\
\hline
\end{tabular}




\section{CONCLUSION}

Natural product research is highly focussed on the interplay of various disciplines of natural sciences. Particularly, microbiology for the isolation of new secondary metabolite producers, molecular biology for the characterisation of the biosynthetic machinery and analytical chemistry for naturally derived products identification and isolated form for the basis of the characterisation of new compounds from actinobacteria. The research describes the isolation of terrestrial actinomycete species that are potent candidates for future unique drug development. Concerning with microbial natural products the effective secondary metabolites production shall be improved by precision engineering.

\section{ACKNOWLEDGEMENT}

The authors are thankful to IIT, SAIF, Madras and Armats Biotek Training and Research Institute for providing facilities to carry out research work.

\section{REFERENCES}

1. Sadaf Mushtaq, Bilal Haider Abbasi, Bushra Uzair, Rashda Abbasi. Natural products as reservoirs of novel therapeutic agents. EXCLI Journal, 2018; 17:420-451.

2. Gurnani N, Mehta D, Gupta M, Mehta BK. Natural products: Source of potential drugs. Afr J Basic Appl Sci, 2014; 6:171-86.

3. Berdy J. Bioactive microbial metabolites : a personal view. J Antibiot (Tokyo). 58(1):1-26. Erratum in: J Antibiot (Tokyo). 2005; 58(4):C-1.

4. Gupta C, Prakash D, Gupta S. Natural useful therapeutic products from microbes. J Microbiol Exp, 2014; 1: 00006.

5. Zhi-Qiang Xiong, Jian-Feng Wang, Yu-You Hao and Yong Wang. Recent Advances in the Discovery and Development of Marine Microbial Natural Products. Mar. Drugs, 2013; 11:700-717.

6. Berdy, J. Bioactive microbial metabolites. J. Antibiot. 2005; 58 : $1-26$.

7. Haidan Yuan, Qianqian Ma, Li Ye and Guangchun Piao. The Traditional Medicine and Modern Medicine from Natural Products. Molecules, 2016; 21:559.

8. Hong JY. Natural product diversity and its role in chemical biology and drug discovery. Curr. Opin. Chem. Biol, 2011; 15:350-354.

9. Rosén J, Gottfries J, Muresan S, Backlund A, Oprea TI. Novel chemical space exploration via natural products. J. Med. Chem, 2009; 52:1953-1962.

10. Butler MS. Natural products to drugs: Natural productderived compounds in clinical trials. Nat. Prod. Rep, 2008; 25: 475-516.

11. Girish Mahajan and Lakshmi Balachandran. Biodiversity in Production of Antibiotics and Other Bioactive Compounds. Adv Biochem Eng Biotechnol, 2015; 147: 37-58.

12. Newman DJ, Cragg GM. Microbial anti tumor drugs: natural products of microbial origin as anticancer agents. Curr Opin Investig Drugs, 2009; 10(12):1280-1296

13. Raiijmakers JM, Mazzola M. Diversity and natural functions of antibiotics produced by beneficial and plant pathogenic bacteria. Annu Rev Phytopathol, 2012; 50:403-424.

14. Demain AL, Sanchez S. Microbial drug discovery: 80 years of progress. J Antibiot, 2009; 62:5-16.

15. Subramani R, Aalbersberg W. Marine actinomycetes: An ongoing source of novel bioactive metabolites. Microbiol Res, 2012; 167:571-80.

16. Williams ST, Goodfellow M, Alderson G. Genus Streptomyces Waksman and Henrici 339 AL. In: Williams ST, Sharpe ME, Holt JG (eds). Bergey's manual of systematic bacteriology, 1989; 2452-2492.

17. Williams ST, Goodfellow M, Alderson G, Wellington EMH, Sneath PHA, Sackin MJ. Numerical classification of Streptomyces and related genera. J Gen Microbiol, 1983; 129:1743-1813.

18. Lucas X, Senger C, Erxleben A, Grüning BA, Döring K, Mosch J, Flemming S, Günther S. Streptome DB: a resource for natural compounds isolated from Streptomyces species. Nucl Acids Res 41(Database Issue), 2013; D1130-D1136.
19. Marian Valko, Mario Izakovic, Milan Mazur, Christopher J. Rhodes and Joshua Telser. Role of oxygen radicals in DNA damage and cancer incidence. Molecular and Cellular Biochemistry, 2004; 266: 37-56.

20. Halliwell B, GutteridgeJMC: Free Radicals in Biology and Medicine. Claredon Press, Oxford, 1989.

21. Kehrer JP: Free-radicals as mediators of tissue-injury and disease. Crit Rev Toxicol, 1993; 23: 21-48.

22. Winterbourn CC. Superoxide as an intracellular radicals ink. Free Rad Biol Med 14: 1993; 85-90.

23. Liochev SI, Fridovich I: The role of $\mathrm{O}_{2}$-center-dot- in the production of ho-center-dot - in-vitro and in-vivo. Free Rad Biol Med, 1994; 16: 29-33.

24. Miller DM, Buettner GR, Aust SD. Transition-metals as catalysts of autoxidation reactions. Free Rad Biol Med, 1990; 8: 95-108.

25. Abheri Das Sarma, Anisur Rahaman Mallick and A.K. Ghosh. Free Radicals and Their Role in Different Clinical Conditions: An Overview. International Journal of Pharma Sciences and Research, Vol: 1(3), 2010; 185-192.

26. R. T. Oakley, Prog. Inorg. Chem., 1998, 36, 299.

27. Porter JN, Wilhelm JJ. Tresner HD. Method for the preferential isolation of actinomycetes from soils. Appl. Microbiol, 1960; 8:174-8.

28. Burkholder PR, Sun SH, Ehrlich J, Anderson L. Criteria of speciation in the genus Streptomyces. Ann. New York Acad. Sci, 1954; 60:102-23.

29. Sambamurthy $\mathrm{K}$ and Ellaiah P. A new streptomycete producing neomycin (B and C) complex S. marinensis (PartI). Hind. Antibiot. Bull, 1974; 17: 24-28.

30. Khalaf NA, Shakya AK, Al-othman A, El-agbar Z, Farah H. Antioxidant activity of some common plant. Turk J Biol, 2008; 32:51-5.

31. Lokesh Deb SK, Dubey, Avijeet Jain, Amit Kumar Jain, Pandian GS. Free radical scavenging activity of aqueous n- butanol fraction of Prunus Persica aqueous extract. Journal of Natural Remedies, 2009; 9(2); 152-158.

32. Arnao MB, Cano A, Acosta M. The hydrophilic and lipophilic contribution to total antioxidant activity. Food Chem, 2001; 73:239-44.

33. Prieto $\mathrm{P}$, Pineda $\mathrm{M}$, Aguilar M. Spectrophotometric quantitation of antioxidant capacity through the formation of a phosphomolybdenum complex: specific application to the determination of vitamin E. Analytical Biochemistry, 1999; 269: 337-341.

34. Oyaizu M. Studies on products of browning reaction: antioxidative activities of products of browning reaction prepared from glucosamine. Jpn. J. Nutr, 1986; 44: 307315

35. Harindran J, Gupte TE and Naik SR. HA-1-92, a new antifungal antibiotic produced by Streptomyces CDRIL-312: Fermentation, isolation, purification and biological activity. World J. Microbiol. Biotechnol, 1999; 15: 425-430.

36. Liu X, Dong M, Chen X, Jiang M, Lv X and Yan G. Antioxidant activity and phenolics of endophytic Xylaria sp. from Ginkgo biloba. Food Chemistry, 2007; 105: 548-554.

37. Spanos GA and Wrosltad RE. Influence of processing and storage on the phenolic composition of Thompson seedless grape juice. Journal of Agricultural \& Food Chemistry, 1990; 38: 1565-1571.

38. Stahl E. Thin Layer Chromatography. 2nd ed. Springer Pvt. Ltd. New Delhi 2005, 85.

39. Lyons AJ, Pridham TG. Standard antimicrobial spectra as aids in characterization and identification of actinomycetales. Develop. Indus. Microbiol, 1973; 14: 205-211.

40. Jessy Padma B, Saraswathi K, Arumugam P, Anna Shiny R. Isolation, characterization and evaluation of antioxidant activities of secondary metabolites producing actinomycetes of terrestrial origin. International Journal of Research in Medical Sciences, 2018; 6(3):1017-1028.

41. Dehpour AA, Ebrahimzadeh MA, Nabavi SF, Nabavi SM. Antioxidant activity of methanol extract of Ferula assafoetida and its essential oil composition. Grasas Aceites, 2009; 60: 405-412.

42. Wickens AP. Aging and the free radical theory, Respiratory Physiology, 2001; 128:379-391.

43. Miller DD. Mineral. In: Fennema, O.R. (Ed.), Food Chemistry, 1996; Marcel Deckker, New York, 618-649. 
44. Yildirim A, Mavi A, Kara AA. Determination of antioxidant and antimicrobial activities of Rumex crispus L. extracts. J. Agric. Food Chem, 2001; 49:4083-4089.

45. Nabavi SM, Ebrahimzadeh MA, Nabavi SF, Fazelian M, Eslami B. In vitro antioxidant and free radical scavenging activity of Diospyros lotus and Pyrus boissieriana growing in Iran. Pharmacognosy Magazine, 2009; 4: 123-127.

46. Meir S, Kanner J, Akiri B, Hadar SP. Determination and involvement of aqueous reducing compounds in oxidative systems of various senescing leaves. J Agric Food Chem, 1995; 43: 1813-1817.

47. Stadtman ER. Metal ion-catalyzed oxidation of proteins: Biochemical mechanism and biological consequences. Free Radical Biology and Medicine, 1990; 9:315-325.

48. David M. Pereira, Patrícia Valentao, Jose A. Pereira and Paula B. Andrade. Phenolics: From Chemistry to Biology. Molecules, 2009; 14, 2202-2211.

49. Valentao P, Fernandes E, Carvalho F, Andrade PB, Seabra RM, Bastos ML. Hydroxyl radical and hypochlorous acid scavenging activity of small centaury (Centaurium erythraea) infusion. A comparative study with green tea (Camellia sinensis). Phytomedicine, 2003; 10: 517- 522.

50. Valentao P, Fernandes E, Carvalho F, Andrade PB, Seabra RM, Bastos ML. Antioxidative properties of cardoon (Cynara cardunculus L.) infusion against superoxide radical, hydroxyl radical and hypochlorous acid. J. Agric. Food Chem, 2002; 50: 4989-4993.

51. Valentao P, Fernandes E, Carvalho F, Andrade PB, Seabra RM, Bastos ML. Antioxidant activity of Hypericum androsaemum infusion: scavenging activity against superoxide radical, hydroxyl radical and hypochlorous acid. Biol. Pharm. Bull, 2002; 25: 1320-1323.

52. Valentao P, Fernandes E, Carvalho F, Andrade PB, Seabra RM, Bastos ML. Studies on the antioxidant activity of Lippia citriodora infusion: scavenging effect on superoxide radical, hydroxyl radical and hypochlorous acid. Biol. Pharm. Bull, 2002; 25: 1324-1327.

53. Heim KE, Tagliaferro AR, Bobilya DJ. Flavonoid antioxidants: chemistry, metabolism and structure-activity relationships. J. Nutrit. Biochem, 2002; 13: 572-584.

54. Paya M, Halliwell B, Hoult JRS. Interactions of a series of coumarins with reactive oxygen species. Scavenging of superoxide, hypochlorous acid and hydroxyl radicals. Biochem. Pharmacol, 1992; 44: 205-214.

55. Choi HR, Choi JS, Han YN, Bae SJ, Chung HY. Peroxynitrite scavenging activity of herb extracts. Phytother. Res, 2002; 16: 364-367.
56. Parr AJ, Bolwell JP. Phenols in the plant and in man. The potential for possible nutritional enhancement of the diet by modifying the phenols content or profile. J. Sci. Food Agric, 2002; 80: 985-1012.

57. Cos P Ying L, Calomme M, Hu JP, Cimanga K, Poel BV, Pieters L, Vlietinck AJ, Berghe DV. Structure-activity relationship and classification of flavonoids as inhibitors of xanthine oxidase and superoxide scavengers. J. Nat. Prod, 1988; 61: 71-76.

58. Cushnie TPT, Lamb AJ. Antimicrobial activity of flavonoids. Int. J. Antimicrob. Agents, 2005; 26: 343-356.

59. Aron PM, Kennedy JA. Flavan-3-ols: Nature, occurrence and biological activity. Mol. Nutr. Food Res, 2008; 52: 79-104.

60. Wall PE. Merck Ltd, Poole, Dorset, UK, 2000; Chromatography: Thin-layer (PLANAR)/Spray Reagents.

61. Vitale M, Scatassa ML, Cardamone C, Oliveri G, Piraino C, Alduina R, Napoli C. Staphylococcal food poisoning case and molecular analysis of toxin genes in Staphylococcus aureus strains isolated from food in Sicily, Italy. Foodborne Pathog Dis, 2015; 12(1):21-3.

62. Jie MSF and Choi CYC: J. Int. Fed. Clin. Chem, 1991; 3: 122.

63. Betz JM, Gay ML, Mossoba MM, Adams S and Portz BS: J AOAC Int. 1997; 80: 303.

64. Andrew Marston: Role of advances in chromatographic techniques in phytochemistry. Phytochemistry, 2007; 68:2785-2797.

65. Ser H, Ab mutalib NS, Yin WF, Chan KG, Goh BH and Lee LH. Evaluation of antioxidative and cytotoxic activities of Streptomyces pluripotens MUSC 137 isolated from mangrove soil in Malaysia. Frontiers in Microbiology. 2015; 6:1398.

66. Elaiyaraja A, Chandramohan G. Comparative phytochemical profile of Indoneesiella echioides (L.) Nees leaves using GC-MS Journal of Pharmacognosy and Phytochemistry, 2016; 5(6):158-171.

67. Saraswathi K, Sivaraj C and Arumugam P. Antioxidant Activities, Thin Layer Chromatographic Analysis and GCMS Analysis of Capsicum annuum L.: A Comparison of Green and Red Chilli. J. Biol. Chem. Research, 2019; Vol. 36, No. 1: 184197.

68. McGinty D, Letizia CS. and Api AM. Fragrance material review on phytol. Food Chem Toxicol, 2010; 48: Suppl (3): S59-63.

69. Justyna Mierziak, Kamil Kostyn and Anna Kulma. Flavonoids as Important Molecules of Plant Interactions with the Environment. Molecules, 2014; 19, 16240-16265.

70. Jain PK and Himanshu Joshi, Coumarin: Chemical and Pharmacological Profile, Journal of Applied Pharmaceutical Science, 2012; 02 (06): 236-240 